Indonesian Science Education Research
(ISER)

\title{
THE EFFECT OF INQUIRY TRAINING LEARNING MODELS USING MACROMEDIA FLASH ON STUDENTS LEARNING OUTCOMES OF PHYSICAL SUBJECT
}

\author{
Sri Arfani $\mathrm{Hs}^{1}$, Sehat Simatupang ${ }^{1}$ \\ ${ }^{1}$ Department of Physics Faculty of Mathematics and Natural Sciences, Medan State University \\ *E-mail: yulestari2307@gmail.com
}

Accepted: September $7^{\text {th }}, 2020$. Published: October $6^{\text {th }}, 2020$

\begin{abstract}
This study aims to determine the effect of the inquiry training learning model using macromedia flash on student learning outcomes on momentum and impulse material in class X semester II Teladan Medan academic year 2017/2018. This type of research is a quasi experiment with two group research designs pre-test and post-test. The population in the study were all students of class X Senior High School Teladan Medan. Sampling was done by random sampling, namely class X-3 as an experimental class by applying the inquiry training learning model using macromedia flash and class $\mathrm{X}-2$ as a control class that applies conventional learning, each class consists of 40 students. The instrument used was in the form of a multiple choice test of 15 questions that had been validated by the validator and student activity observation sheets in the experimental class and the control class. The results of pre-test data processing showed that the pre-test mean value of the experimental class was 31.83 and the control class was 30.49 , the post-test average value of the experimental class was 75.33 and the control class was 64.83. The average score of the experimental class student activity reached $66.72 \%$ in the active category and the control class reached $54.50 \%$ in the less active category. The results obtained show that there was an effect of the inquiry training learning model using macromedia flash on student learning outcomes on momentum and impulse material in class $\mathrm{X}$ Senior High School Teladan Medan academic year 2017/2018.
\end{abstract}

Keywords: inquiry training model, macromedia flash, learning. 


\section{Introduction}

National education system law No. 20 of 2003 states that education is a conscious and planned effort to create an atmosphere of learning and the learning process so that students actively develop their potential to have spiritual-religious strength, self-control, personality, intelligence, noble character and skills needed by themselves, society, nation and state. National education aims to develop the potential of students to become human beings who believe and have devotion to God Almighty, have noble character, are healthy, knowledgeable, capable, creative, independent and become democratic and responsible citizens.

Education plays a very important role for the development of students so that later they become quality human resources. Success in the field of education has earned the quality of a nation worldwide recognition, however, in reality the quality of education in Indonesia is still very concerning. PISA (Program for International Student Assessment) in 2015 shows the low ability of Indonesian students, in the field of Science Indonesia is ranked 62, Mathematics 63, and Reading 64 out of 70 countries (Pisa Indonesia, 2016).

Related to this, the researcher conducted a preliminary study conducted by researchers at the Teladan Medan Private High School by conducting interviews with teachers in the field of physics, that the physics exam results were not satisfactory where the average score of students was 50-70, when viewed from the Minimum Completeness Criteria ( $\mathrm{KKM}$ ) set by the school is 75 . This is also in line with the results of the questionnaire that the researcher has given to 47 students of Medan Teladan Private High School. Based on the data obtained, $51 \%$ thought physics is a difficult subject to understand, 32\% thought physics was mediocre, $11 \%$ thought physics was fun and $6 \%$ thought it was boring.

Low student learning outcomes are due to teachers tend to use conventional learning with the lecture method so that teachercentered learning activities and the lack of utilizing media in learning result in students becoming passive in the learning process. The way the teacher teaches has not created an attractive learning atmosphere so that students have a tendency to not actively ask questions if they encounter difficulties in the learning process.

Based on the results of these observations, the teacher must be able to improve students' low learning outcomes for physics by choosing the appropriate learning model used to increase student activeness, understanding and learning achievement. One of the appropriate learning models in this study is to use the inquiry training model. Hani, et al (2016) stated that the inquiry training learning model aims to train students' abilities in researching, explaining phenomena and solving problems scientifically. The inquiry training model can help students be active in the psychomotor skills and intellectual skills needed to ask questions and find answers.

The inquiry training learning model is designed to bring students directly into the scientific process through exercises that can condense the scientific process into a short period of time, the goal is to help students develop discipline and develop the intellectual skills needed to ask questions and find answers based on curiosity, through the inquiry training learning model students are expected to actively ask questions about why something happened then seek and collect and process data logically to further develop intellectual strategies that can be used to find answers to these questions (Joyce, et al., 2009).

In the inquiry training learning model, there are three key principles, namely tentative knowledge, humans have a natural curiosity, and humans develop individually independently. The first principle requires a continuous research process, the second principle indicates the importance of students doing exploration, and the third independence, will lead to the introduction of scientific identity and attitude, the general purpose of the inquiry training model is to help students develop intellectual skills and other skills, such as proposing questions and finding (looking for) answers that originate from student curiosity (Pardede and Manurung, 2016).

The application of the inquiry training learning model can be assisted by using the macromedia flash learning media. The use of macromedia flash learning media encourages students to use the senses of sight and hearing in learning so that the teaching and learning 
process becomes innovative and not boring for students.

Inquiry training learning has been researched before, namely Pardede and Manurung (2016) state that the inquiry training learning model is more effective in improving learning outcomes. This is because the inquiry training learning model involves students actively discovering their own knowledge through the process of inquiry. Harefa, et al (2016) revealed that the ability of students 'scientific knowledge of physics using inquiry training learning was better than the ability of students' scientific knowledge using direct instruction learning. Harahap, et al (2016) state that the learning process with the inquiry training model is able to create a scientific basis for students, develop creativity in solving problems and improve science process skills. Students are really placed as learning subjects, the teacher's role in teaching by inquiry training is as a mentor and facilitator. Salim, et al (2014) stated that learning with the inquiry training model showed an increase in learning outcomes in the cognitive aspects. Singh (2014) states that the inquiry training model has a significant effect on affective, cognitive development and learning levels. Anggi and Sinuraya (2016) state that the inquiry training learning model can improve student learning outcomes and activities better than conventional learning.

As for the obstacles in previous research, namely Pardede and Manurung (2016), the lack of assistance with creative learning media in the learning process, Sirait (2012), the number of students in each group resulted in a commotion, an effort that researchers will make to overcome these weaknesses is to provide an inquiry training model accompanied by macromedia flash as one of the learning media, good group organizing.

\section{Research Methods}

This research was conducted at the Medan Teladan High School even semester 2017/2018 academic year. The population in this study were all students of class X Senior high school Private Teladan Medan Academic year 2017/2018 which consisted of 4 classes. The research sample consisted of two classes representing populations with the same characteristics. Sampling in this study was taken randomly, namely by using random sampling. class X IPA-3 as an experimental class treated using the inquiry training learning model using macromedia flash and class $\mathrm{X}$ IPA-2 as a control class treated using conventional learning.

This type of research is a quasiexperimental research and the research design used was a two group pretest-posttest design. The design of this research can be seen in table 1 :

Tabel 1.two group pretest-posttest design

\begin{tabular}{|l|l|l|l|}
\hline Class & Pretest & Treatment & Postest \\
\hline Experiment & $\mathrm{T}_{1}$ & $\mathrm{X}$ & $\mathrm{T}_{2}$ \\
\hline Control & $\mathrm{T}_{1}$ & $\mathrm{Y}$ & $\mathrm{T}_{2}$ \\
\hline
\end{tabular}

Information:

$\mathrm{T} 1=$ initial ability test (pretest)

$\mathrm{T} 2$ = final ability test (posttest)

$\mathrm{X}=$ treatment in the experimental class, namely the application of the inquiry training learning model $\mathrm{Y}=$ treatment in the control class, namely the application of conventional learning

The stages in the research were the researcher gave a pretest to the experimental class and the control class. The instrument used in the study was a multiple choice test consisting of 15 questions. The learning outcomes test is in the form of multiple choice questions that are distributed in the cognitive domain bloom taxonomy, namely knowledge (C1), understanding (C2), application (C3), analysis (C4), evaluation (C5), and creating (C6). The first test of learning outcomes was standardized using the content validity test. After the pretest data were obtained, data analysis was carried out using the normality test, namely the Lilliefors test and the homogeneity test. After that, the two-party ttest hypothesis was tested to determine the students' initial abilities in the two sample groups. After seeing the students' initial abilities were the same, then the researcher gave a different treatment, namely teaching the subject matter using the inquiry training learning model using macromedia flash in the 
experimental class and conventional learning in the control class. Then provide a post test and analyze the data using the one-party t test to determine the effect of the treatment of the inquiry training learning model using macromedia flash on student learning outcomes.

\section{Results and Discussion}

\section{a. Results}

The data described in this study include data on student learning outcomes on momentum and impulse material. The pretest was given to both classes, namely the experimental class with the inquiry training learning model and the control class with conventional learning which aims to determine whether the initial abilities of students in both classes are the same or not. The results of the pretest data for the experimental class and control class students can be shown in Figure $1:$ Based on the results of the pretest obtained, the average value of the experimental class pretest was 40.74 and the control class pretest score was 41.20. Furthermore, the experimental class and the control class were given different treatments. In the experimental class using a cooperative type GI model and in the control class using conventional learning. After the two classes were given treatment, each class was given a posture to see the difference due to being given different learning treatments. From the posttest data of the two classes, the average posttest scores for the experimental class were 75.14 and the mean scores of the control class posttest were 59.83 as shown in Figure 1:

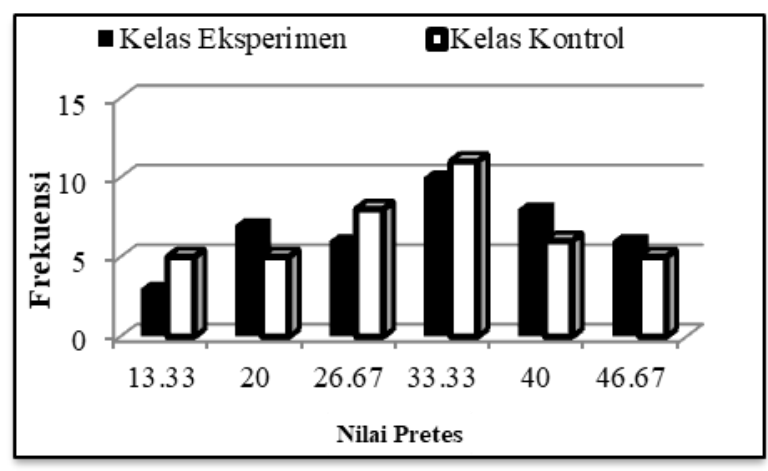

Figure 1. Bar diagram of the class pre-test data experiment and control class
Figure 1 shows that the pretest scores for the experimental class and the control class are not much different, this means that the two sample classes have the same initial ability.

During the learning process, researchers assessed the activities and attitudes of students in class. The aspects assessed are observing puzzling events, collecting and organizing data, collecting experimental data, analyzing experimental data, formulating conclusions. The assessment of student activities in the experimental class and control class for 3 meetings will be presented in Figure 2 and Figure 3:

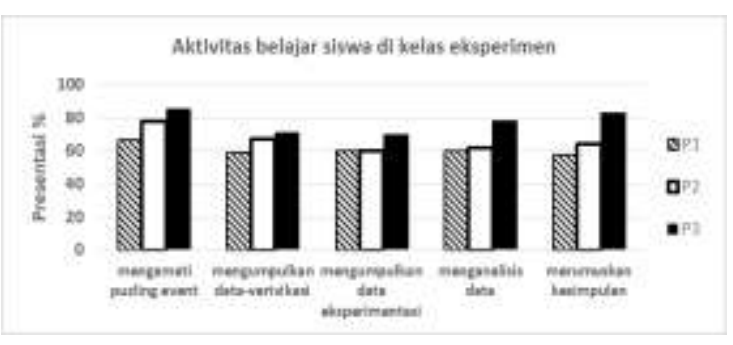

Figure 2. Assessment of activities in the experimental class

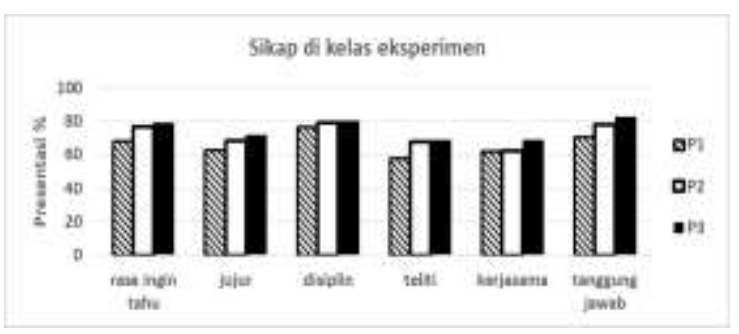

Figure 3. Assessment of activities in the control class

Figures 2 and 3. show that the activities of students in the experimental class have developed higher activity values while receiving learning with the inquiry training learning model using macromedia flash compared to conventional learning.

Attitude assessment was carried out during teaching and learning activities which consist of three meetings. The aspects assessed are curiosity, honesty, discipline, thoroughness, creativity, cooperation. Assessment of student attitudes in the experimental class will be presented in Figure 4: 


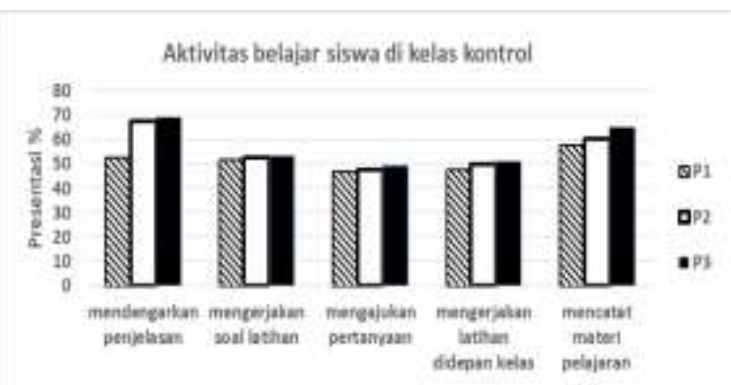

Figure 4. Attitude assessment in the control class

Figure 4 shows that the attitudes of students in the experimental class have increased while receiving the inquiry training learning model using macromedia flash.

The frequency distribution of post-test data for students in the experimental class and control class can be visualized in Figure 5:

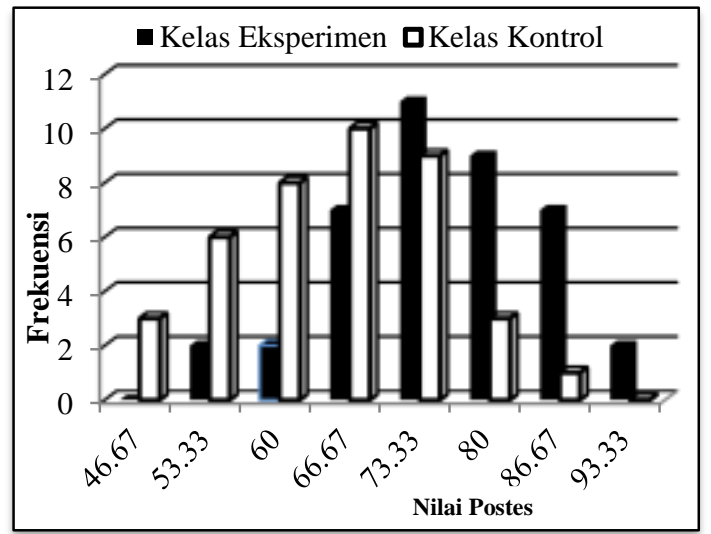

Figure 5. Bar chart of the experimental class and control class post-test data

Figure 5 shows that the scores achieved by students in the experimental class were higher than those in the control class.

\section{b. Discussion}

The results showed that there was an effect of the application of the inquiry training model using macromedia flash on student learning outcomes on the subject matter of momentum and impulse in Class X Semester II Teladan Medan T.P Private High School 2017/2018. This is shown from the acquisition of an average pretest score of students in the experimental class of 31.83 and in the control class the average score of the students' pretest was 30.49. After being given different treatments, the average post-test score of the experimental class was 75.33 and the average control class learning outcomes were 64.83. The improvement of student learning outcomes in the experimental class using the inquiry training learning model using macromedia flash is better than the conventional learning model. This is because the inquiry training learning model can increase interest and require students to be more active in learning physics and invite students to investigate directly the problems that have been presented at the beginning of learning.

The inquiry training learning model exposes students to a confusing situation (puzzling event) that encourages students' curiosity about a problem that must be proven through an experiment in groups so that students are moved to find out their own answers to existing problems, thus the inquiry training learning model involves students fully to find the material being studied and link it to the events of everyday life.

The inquiry training learning model teaches students to learn to verify, collect experimental data and work together in groups to find answers to problem formulations and put forward hypotheses about what was proven during the experimental process and analyze it and relate it to daily life events. This is supported by the opinion of Joyce, et al (2009: 214) which states that the inquiry training learning model offers active and autonomous learning, especially when students formulate questions and test ideas. This is also reinforced by research conducted by Lumbanraja, et al (2017) which states that the magnitude of the increase in student learning outcomes in the experimental class is because the inquiry training learning model can help students to directly construct knowledge through every activity that has been designed in the learning phase. Hannum and Bukit (2014) state that the inquiry learning model is a learning model that is considered in accordance with the development of modern learning psychology which considers learning as a process of changing behavior thanks to experience.

Research related to the inquiry training learning model has been researched by Nasution and Sinuraya (2015) which states that the physics learning outcomes of students who 
use the inquiry training learning model have a higher average value than conventional learning. Wahyuni and Sipapaga (2015), which states that the learning outcomes in the experimental class taught by the inquiry training learning model are higher than the learning outcomes in the control class with conventional learning.

Using the learning model, using macromedia flash makes students more interested in learning because of the attractive appearance, containing physics material and physics animation. This certainly supports the student learning process in mastering the material so that it can improve learning outcomes compared to learning outcomes with conventional learning.

Learning with the inquiry training model can also increase the activity and attitudes of students, in this observation activity assessment is carried out in the experimental class and the control class, while the attitude assessment is only carried out in the experimental class, where the results of activity observations and attitudes in the experimental class have increased from the meeting. I until the meeting III. An increase in student activity and attitudes for the better certainly has a positive influence on student learning outcomes. The increase in student attitudes is increasing because students are getting used to understanding tasks individually or in groups when conducting experiments and being responsible for completing their assignments. This is also in line with research conducted by Waramita and Simatupang (2014) which experienced an increase in student learning activeness while using the inquiry training learning model using simple tools, an increase from meeting I to meeting III and included in the good category.

During learning with the inquiry training learning model using macromedia flash there were several problems in conducting research, it was seen that some students were confused about the stages to be carried out during learning this was because students had previously been used to the learning system with the lecture method so that the class atmosphere became not conducive, therefore, for the next researcher before learning begins, it is better to provide direction in the stages that will be carried out in learning so that a conducive atmosphere is created during learning and also for further researchers it is hoped that more puzzling events will be prepared in everyday life so that students are more motivated to find the answers given.

\section{Conclusion}

This study shows that there is an effect of the application of the inquiry training learning model using macromedia flash on learning outcomes on momentum and impulse material in class X semester II Teladan Medan T.P Private High School 2017/2018. Student cognitive learning outcomes in the experimental class are better than conventional learning outcomes. Student learning activities taught with the inquiry training learning model using macromedia flash were higher than student learning activities taught by conventional learning and student attitudes during learning with the inquiry training learning model using macromedia flash experienced an increase in each meeting. This study shows that there is an effect of the application of the inquiry training learning model using macromedia flash on learning outcomes on momentum and impulse material in class X semester II Teladan Medan TP Private High School 2017/2018. Student cognitive learning outcomes in the experimental class are better than conventional learning outcomes. Student learning activities taught with the inquiry training learning model using macromedia flash were higher than student learning activities taught by conventional learning and student attitudes during learning with the inquiry training learning model using macromedia flash experienced an increase in each meeting.

\section{Suggestion}

For teachers and further researchers who use the inquiry training learning model in order to prepare more puzzling events in everyday life so that students are more motivated to find answers to the problems given and before learning begins, it is better to provide direction in the stages to be carried out in learning so that create a conducive atmosphere during lessons. 


\section{References}

Anggi, J. T., \& Sinuraya, J. (2016). Pengaruh Model Pembelajaran inquiry Training terhadap Hasil Belajar Fisika Siswa pada Materi Pokok Listrik Dinamis di SMA PAB 8 Saentis Deli Serdang T.P 2014/2015. Jurnal Inpafi. 4 (4).

Hani, W.F., Indrawati., \& Subiki. (2016). Pengaruh Model Inquiry Training disertai Media Audiovisual terhadap Hasil Belajar dan Retensi Hasil Belajar Siswa pada Pembelajaran IPA (Fisika) di MTs. Jurnal Pembelajaran Fisika. 4 (4) :315 -320.

Hannum, F. \& Bukit, N. (2014). Pengaruh Model Pembelajaran Inquiry Training terhadap Hasil Belajar Siswa. Jurnal Inpafi. 2 (4) : 139-147.

Harahap, M. B., Manurung, S.R., Marbun, M.A., \& Mihardi, S. (2016). Effect Model Inquiry Training on Student's Science Process Skill. Advances in Social Sciences Research Journal. 3: (11) 38-42.

Harefa, E., Sirait, M., Ginting, E. M., (2016). Pengaruh Model Pembelajaran Inquiry Training dan Keterampilan Berpikir Kritis terhadap Pengetahuan Ilmiah Siswa Kelas X. Jurnal Pendidikan Fisika. 5 (2) : 81-86.

Joyce, B., Weil, M., \& Calhoun, E. (2009). Model-model Pengajaran Edisi Delapan. Yogyakarta : Pustaka Belajar.

Siswa. Jurnal Pendidikan Fisika. 6 (2): 116111.

Nasution, N, A., \& Sinuraya, J. (2015). Pengaruh Model Pembelajaran Inquiry Training dan Motivasi terhadap Hasil Belajar Siswa pada Materi Pokok Fluida Statis Kelas X Semester II salah satu SMA Negeri di Percut Sei Tuan T.P. 2014/2015. Jurnal Inpafi. 3 (4): 119-126.

Pardede, D.M., \& Manurung, S. R. (2016). Pengaruh Model Pembelajaran Inquiry Training dan Motivasi terhadap Hasil Belajar Fisika Siswa. Jurnal Pendidikan Fisika. 5 (1): 1-6.

Salim, A. R., Sumardi, K., \& Rakhman, M. (2014). Pembelajaran Inquiry Training untuk meningkatkan Prestasi Belajar Siswa SMK. Journal of Mechanical Engineering Education. 1 (2): 200-206.

Singh,V. (2014). Effectiveness Of Inquiry Training Model For Teaching. Chemistry scholarly research journal for interdisciplinary studies. 2 (15):2344-2349.

Sirait, R. (2012). Pengaruh Model Pembelajaran Inquiry Training terhadap Hasil Belajar Siswa pada Materi Pokok Usaha dan Energi Kelas VIII MTs N-3 Medan. Jurnal Pendidikan Fisika. 1 (1): 21-26.

Wahyuni, I. \& Sipapaga, D. S. (2015). Pengaruh Model Pembelajaran Inquiry Training terhadap Hasil Belajar Siswa pada Materi Pokok Listrik Dinamis. Jurnal Ikatan Alumni Fisika Universitas Negeri Medan. 1 (1) : 22-28.

Waramita \& Simatupang, S., (2014), Pengaruh Model Pembelajaran Inquiry Training dengan menggunakan Alat Sederhana terhadap Hasil Belajar Siswa Fisika SMP. Jurnal Inpafi. 2 (3) : 198-206. 